\title{
Improvement Of Service Passengers Land Transportation Through Marketing Communication Strategies (Analysis: Royaltrans Jakarta - Route Bekasi-Jakarta)
}

\author{
Afrina Sari \\ afrina.sari@budiluhur.ac.id \\ Universitas Budi Luhur
}

\begin{abstract}
The policy agreement between the government of Jakarta and Bekasi City is to apply toll road use for four-wheeled vehicles based on odd-even vehicle numbers. The Jakarta City Government is preparing a solution by preparing a premium RoyalTransJakarta land transportation, with affordable tariffs and convenient facilities. This research aims to; 1) analyzing Royalstrans Jakarta's marketing communication strategy to the user community. 2) steps in developing information and increasing passengers. This research method uses a qualitative approach with descriptive methods with data collection techniques through observation and interviewees. Data analysis is done by triangulation of sources and data. The informants interviewed were 2 drivers, 2 conductors and 2 passengers at RoyalTrans-Jakarta. The results showed that 1) RoyalTrans marketing communication strategy, among others, using Banners, Talk Show via Radio, using WhatsApp in developing networks between permanent passengers of RoyalTrans buses. 2) The steps taken are; a) invites the information dissemination team to provide knowledge about royalTrans. b). facilitate information via WhatsApp to provide scheduled departure information from Bekasi and from Jakarta. c). maintain relationships with passengers and create a sense of comfort and service.
\end{abstract}

Keywords: Marketing Communication, WhatsApp Media, Increased Passenger.

\section{Introduction}

The Jabodetabek Transportation Management Agency (BPTJ) of the Ministry of Transportation began implementing special policies to reduce the increasingly severe congestion on the Jakarta - Cikampek toll road section. On March 12, 2018 a trial of premium transportation was carried out. This is one policy in applying odd-even arrangements. Regulations apply to private vehicles entering the toll doors of West Bekasi and East Bekasi towards the direction of Jakarta. This policy comes into force every Monday - Friday at 06.00 09.00 WIB, except holidays. Thus referring to the provisions of the time at ataş, later the oddnumbered private vehicles can only access the toll doors of West Bekasi and East Bekasi tolls in the direction of Jakarta on odd dates.

According to Transportation Minister Budi Karya Sumadi, it was confirmed that the implementation of traffic policy at the Jakarta-Cikampek Toll Road had been thoroughly studied. The Ministry of Transportation has coordinated with various relevant stakeholders to 
implement the policy, including among them transporter business actors and associations in the transportation sector.

The Ministry of Transportation issues a traffic policy on the Jakarta-Cikampek Toll Road to break down congestion. The policy is also the way the Government encourages private vehicle users to switch to public transportation modes. The policy package contained in the Minister of Transportation Regulation Number 18 Year 2018 regulates three things. First, regulating the operational hours of freight transportation at $06.00-09.00$ for Group III, IV, V in two directions, namely the section on the Cawang - Karawang Barat segment. This limitation is excluded for vehicles carrying fuel oil (BBM) and gas fuel (CNG). Second, the arrangement of private vehicles through an even-numbered scheme on priority toll gate access in East Bekasi and West Bekasi in the direction of Jakarta. And third, priority lane for East Bekasi public transportation (LKAU) in Jakarta and Transjabodetabek Premium Bus.

According to Bambang Prihartono, Head of BPTJ explained that the three policies issued by the Minister of Transportation were one package. Not only private vehicles, but also freight transport vehicles are arranged[1]. Furthermore, it was said that the policies implemented had gone through studies and trials and were the most appropriate and quick step to reduce the increasingly severe Jakarta - Cikampek toll road congestion. With the policy of regulating goods transportation, starting March 12, 2018 the Class III, IV and V freight transport cars on Monday - Friday at 06.00 - 09.00 WIB may not operate along the Jakarta - Cikampek toll road. While the implementation of the special bus lane policy on the Bekasi - Jakarta toll road does not only apply to TransJabodetabek Buses, it is also intended for all bus transportation including employee buses.

Along with this, TransJakarta provides exclusive mode facilities with premium rates for executive passengers. The new mode offered by Transjakarta is a joint venture between transportation entrepreneurs who have had transportation routes, including route Bekasi - Blok $\mathrm{M}$ and Kuningan - Bekasi. The mode is named RoyalTrans.

RoyalTrans operates starting in March 2018, which initially prepares services with the initial number of Fleet 5 for routes Bekasi-Jakarta, 5 for Bekasi-Kuningan and 5 for Bekasi Grogol. Early in the launch of Moda RoyalTrans, had difficulty finding passengers. Information about the even-numbered odd policies of the city of Bekasi as well as the existence of premium type transportation for executives has been informed through local broadcast media and newspapers between regions. The public's interest is still low, finally low rates appear for Royaltrans users. The initial tariff is Rp. 10,000, - / passenger.

Based on the phenomenon of the emergence of the new program from Transjakarta, this research poses the research questions as follows:

1. What kind of marketing communication strategy is done in marketing Royaltrans transportation mode services?

2. What are the steps taken by RoyalTrans in increasing the number of passengers.

The need to conduct this research is to study marketing communication strategies in increasing the number of passengers and knowing the development of marketing and the relationship of a policy to overcome congestion with the pattern of marketing communication in changing vehicle use. 


\section{Methods}

This study uses a qualitative research approach, (natural inquiry)[2]. The research subjects were chosen based on the considerations of the people who were most competent and involved in marketing communication strategies carried out by Trans-Jakarta organizations in the RoyalTrans-Jakarta service products. Primary data is obtained through direct interviews with resource persons. Informants in this study were 2 Royaltrans-Jakarta bus drivers, 2 conductors, and 2 RoyalTransJakarta bus passengers. The validity of the results of the research was carried out with Trianggulasi Sumber and Data.

\section{Results}

\subsection{Royal Trans Jakarta Marketing Communication Strategy to the User Community}

Royal Trans Jakarta has been operating since March 2018. Starting from 10 fleets directed at the route Bekasi West-Kuningan and route Bekasi Barat-Pasar block M. then it will be upgraded to 10 fleets of Moda transportation. 10 fleets for Bekasi Barat Kuningan route, and 10 fleets for Bekasi Barat - pasar blok M route. Based on interviews with route route managers, it can be explained that the development of the number to 10 fleets for each route was due to increased demand from passengers. RoyalsTrans passengers include exclusive passenger types. Because the function of the mode of transportation is in the morning and evening. Among other times, transportation modes do not operate. So in general it can be said that the Royal Trans bus functions in the morning as an introduction to the user community with the routes that are prepared, namely from Bekasi City to Blok M Market, or from Bekasi City to Kuningan area. Then it functions in the afternoon as the pick-up of the user community from Blok M Market to Bekasi City. Likewise, the pick-up from Kuningan to Bekasi City. The development of 10 fleets to 20 fleets was carried out by the RoyalTrans bus management with marketing communication strategies including using banners, talk shows via radio, using WhatsApp in developing networks between permanent passengers of the RoyalTrans bus.

Based on interviews with 2 RoyalTrans drivers explained that; at the beginning of operations, RoyalTrans Jakarta was rather difficult to get passengers. Many Bekasi passengers prefer the regular Transjakarta busway with a very affordable price of Rp.3,500 per way. With facilities you can transit without paying again. Finally Royaltrans focused more on executive class users. How many steps are taken, namely; provide a special parking area for users of Transjakarta mode services, both exclusive and regular. With parking rates specifically for regular premium transjakarta mode users, it is safer to leave the vehicle in an integrated parking area with a package / per day parking fee of Rp. 10,000, -. At the beginning of the introduction of the Synergy parking program with the RoyalTrans transport bus mode carried out through banners posted on each intersection in the Bekasi city area.

Tarif changes again changed in July 2018, after being considered stable in the number of passengers every day. That is to return to the premium tariff according to the initial tariff plan, which is Rp. 20,000, -. Other than that banners are promoted as follows fig. 1. 


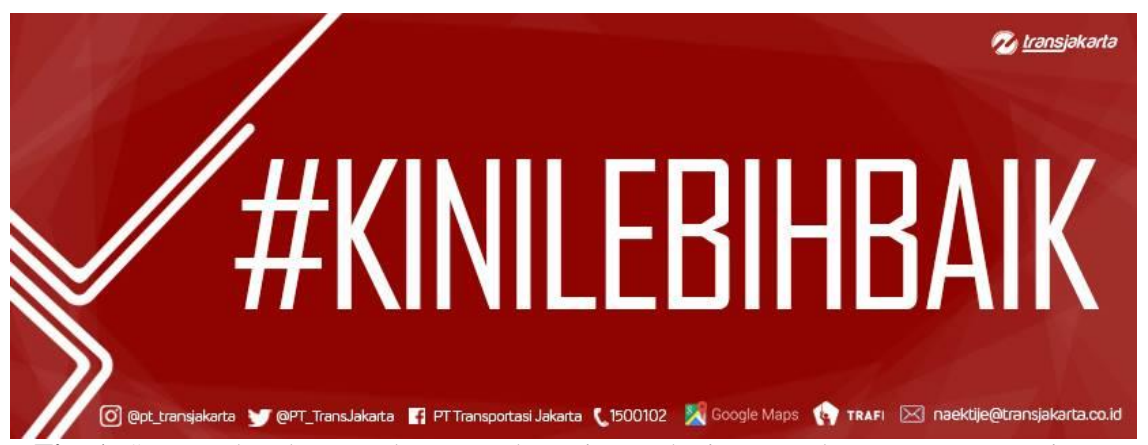

Fig. 1. Steps Taken by Royal Trans Jakarta in Marketing Royal Trans transportation

The steps of Transjakarta management are integrated in implementing travel routes in various ways, including the following:

a) Invite Information Dissemination Teams to Provide Knowledge About Royaltrans.

The RoyalTrans Bus Tariff, which serves four routes from Bekasi, gets a discount of up to $50 \%$. The tariff reduction is related to the enactment of odd and even number policies on the Jakarta-Cikampek toll road in the East Bekasi-Jakarta section. Based on data from the ministry of transportation, the transfer of passengers from private transportation to mass transit is only around $35 \%$. Based on data obtained from the transportation ministry, the transition of public transport private car dealers is the implementation of the three Transportation Policy policy packages "Budi Karya Sumadi". The three policy packages began to take effect in the JakartaCikampek (Japek) toll road through the Governor of the Republic of Indonesia Number 99 of 2018 and the Governor of the Republic of Indonesia Number 18 of 2018. The three policy packages are the odd-even rules for class 1 vehicle plates in the Bekasi Bekasi and East Bekasi directions in Jakarta. Then the making of a special line of bus transportation on the shoulder of the toll road, and the blocking of operational hours of goods vehicles (two-way) in groups III, IV and V. The three policy packages are valid from 12 March 2018 every working day, MondayFriday from 06.00 - 9:00 at the end of pecans and national holidays there is no rule.

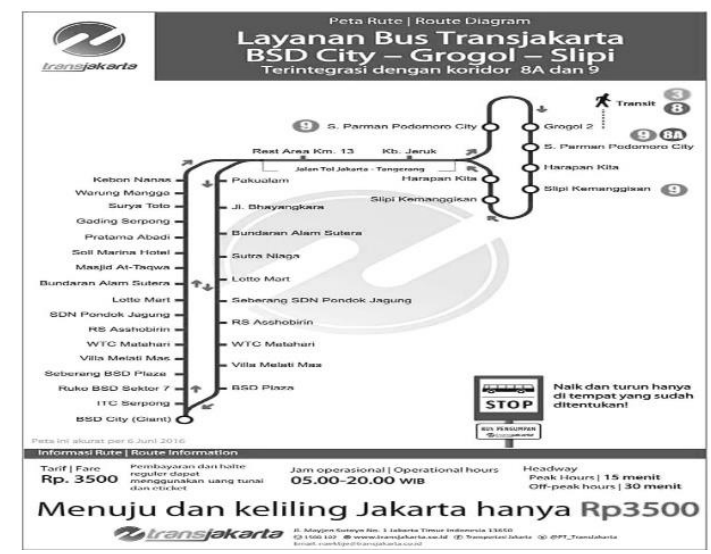

Fig. 2. Transjakarta Bus Promotion 
Tarif reduction information is shared through the official twitter account of PT Transportasi Jakarta @ PT-Transjakarta. The information submitted explains more about travel schedules and travel routes. As illustrated in the following table 1.

Table 1. Bus Routes and Prices

\begin{tabular}{|l|l|l|l|}
\hline No Route & Route Route & Price Dis. 50\% & Normal Price \\
\hline B13 & Bekasi Barat-Blok M & Rp. 10.000 & Rp. 20.000,- \\
\hline B14 & Bekasi Barat-Kuningan & Rp. 10.000,- & Rp. 20.000,- \\
\hline B23 & Bekasi Barat-Tebet & Rp. 10.000,- & Rp. 20.000,- \\
\hline B24 & Bekasi Barat-Kalideres & Rp. 10.000,- & Rp. 20.000,- \\
\hline
\end{tabular}

The routes presented above are guidelines from consumers to use Trans Jakarta bus transportation services. The tariff adjustments imposed are Rp. 15,000 for TransJabodetabek Premium services, routes from Bekasi and Jatiwarna to Jakarta and vice versa, while RoyalTrans services apply a tariff of Rp. 20,000 for routes from Bekasi to Jakarta and vice versa. Rates apply per person for one trip, and only accept cash payments.

\subsection{Fasilitasi informasi melalui WhatsApp}

The Managing Director of PT Transportasi Transjakarta, Budi Kaliwono, planned the West Bekasi area and its surroundings as the operational area of the Royaltrans Jakarta bus. The reason for choosing the West Bekasi region and its surroundings is because it is a densely populated population which is assessed if given premium bus facilities will help reduce the use of private transportation into the Jakarta area. Jabodetabek Transportation management body (PPTJ) accommodates passengers in West Bekasi who want to go to Jakarta by Transjabodetabek bus.

Based on analysis from the management of PT Transportasi Transjakarta; see densely populated West Bekasi. And the transportation fleet has provided services from Transjakarta as many as 25 buses with a tariff of Rp. 3,500, -. But there are some passengers who want to be more comfortable. Then RoyalTrans emerged as an alternative for exclusive class passengers. In the calculation of bus costing, compared to the busway coupled more, the price of a single bus for royalTrans is cheaper.

The Royal Trans Bus has a capacity of 30 seats for passenger seating. The bus also uses a wide foam seat and leather lining with a front facing configuration. Other facilities include a USB port for charging mobile passenger batteries. The tariff charged for passengers is IDR 20,000 for one way to Jakarta.

The form of information facilitated through WhatsApp is as follows:

1. Bus Facilities

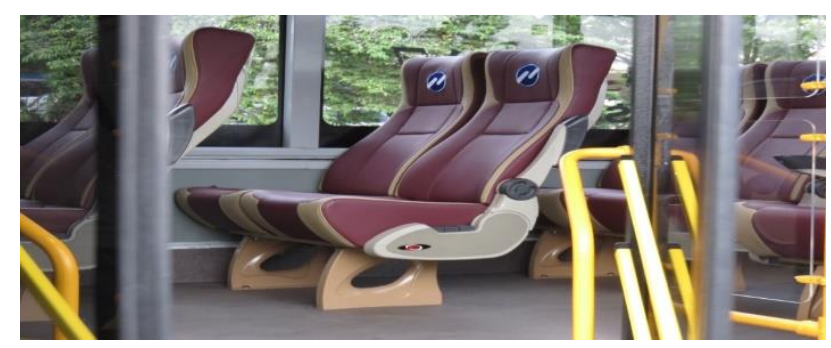

Fig.3. Seat Facilities With System Usage 
Seats provided for RoyalTrans transport bus passengers are provided more exclusively, where seats can be used to be more comfortable. And has a facility to charge cellphones. In addition, seats are provided for 30 passengers, and if all seats are filled, the bus will not fill passengers more than 30 passengers.

\section{Bus Position Waiting}

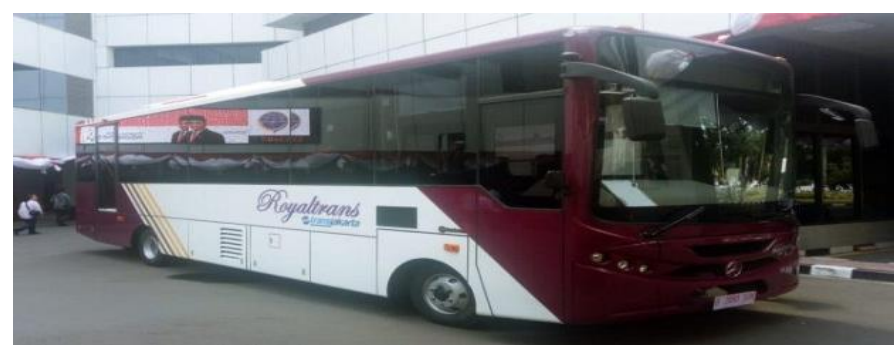

Fig. 4. Information on the Whereabouts of the Bus

The bus information on WhatsApp is information about the existence of the bus, the conector will provide a picture of the bus and explain that the position of the bus is at the Sherter Busway stop and waiting area for passengers. Based on an interview with the Bus conductor, explained that when the bus was scheduled to be operational, the convention would provide information via WhatsApp. Information contains the position of the bus waiting for passengers. Passengers who read information will provide information back.

\subsection{Maintain Relationships With Passengers and Create A Sense Of Comfort and Service}

Relations that were created with transport users of RoyalTrans Jakarta, among others, created intimacy between the conector, driver and passenger. Forms of relationships are created, among others: Giving opinions through chat on WhatsApp; passengers are allowed to provide input for improvements in the services provided by RoyalTrans Jakarta, passenger criticism such as; provide input to change the schedule according to the schedule of returning to work from Jakarta to West Bekasi at 4.00 WIB, then on the advice of the passenger is changed to 4.30 WIB. Other forms of relationship are; make plans for RoyalTrans Jakarta transportation users to plan an event that brings passengers closer to the RoyalTrans Bus crew.

\section{Conclusion}

RoyalTrans marketing communication strategy, among others, using Banners, Talk Show via Radio, using WhatsApp in developing networks between permanent passengers of RoyalTrans buses. The steps taken are; a) invites the information dissemination team to provide knowledge about royalTrans. b). facilitate information via WhatsApp to provide scheduled departure information from Bekasi and from Jakarta. c). maintain relationships with passengers and create a sense of comfort and service. 


\section{References}

[1] www.inews.id/multimedia, "Nyaman Bus Royal Trans Untuk Alternatif Sistem Ganjil-Genap Tol Bekasi," multimedia, 2018.

[2] L. J. Moleong, Metodologi Penelitian Kualitatif. Bandung: Rosda. 